\title{
Parliamentary Administrations in EU Politics: The Sources and Impact of Diversity
}

Anna-Lena Högenauer, University of Luxembourg

Please cite as: Högenauer, Anna-Lena, Parliamentary Administrations in EU Politics: The Sources and Impact of Diversity (November 18, 2019). Available at SSRN:

https://ssrn.com/abstract=3489129

\begin{abstract}
National parliaments tend to delegate a range of tasks related to EU affairs scrutiny to their administrations. However, there is considerable variation in the extent to which national parliaments invest in EU affairs staff. This raises two questions: what is the source of this diversity, and what is its impact on the EU affairs scrutiny of national parliaments? This paper argues that greater investments in EU affairs staff are associated with public Euroscepticism, large parliaments and parliaments with strong scrutiny powers. A large EU staff is, in turn, associated with parliaments that are relatively active in EU affairs scrutiny. This is particularly true for the $15 \mathrm{EU}$ member states that joined before 2004 .
\end{abstract}




\section{Introduction}

Whereas the US literature on parliamentarism has a long tradition of research into parliamentary administrations, the topic had been eclipsed in the European literature for a long time. This has changed in recent years, with the growth of studies on the behaviour of the EP administration (e.g. Egeberg et al. 2013; Winzen 2011; Dobbels and Neuhold 2013) and on national parliaments (e.g. Winzen 2014; Högenauer and Neuhold 2015; Högenauer and Christiansen 2015). Having analysed the behaviour, tasks and roles of parliamentary staff, this literature generally argues that parliamentary administrations perform not only technical tasks - such as the scheduling of meetings and the organization of papers - but also a range of tasks that could potentially influence the extent and content of parliamentary scrutiny. In the case of national parliaments in particular, there is some evidence that the role of administrators grew as the competences of parliaments in EU affairs expanded. More generally, the availability of staff support and own research units influences the ability of parliaments to obtain independent information (Carter 2008).

What the budding literature on the administrations of national parliaments shows is that most parliaments delegate a range of tasks related to EU affairs scrutiny to their administrations. However, it also shows that there is considerable diversity when it comes to the number of staff employed (Högenauer et al. 2016). These findings raise two questions: Firstly, what is the source of the diversity? The early data already suggests that this is not purely the result of the different size of the parliaments (cf. Högenauer and Christiansen 2015).

Secondly, what is the effect of that diversity? The investments in staff are presumably meant to achieve something. One could envisage two possible scenarios: The first - negative scenario is one of bureaucrats running wild. Disinterested politicians delegate the scrutiny of EU affairs to administrators, who then perform it as they see fit. With one or two possible exceptions, the existing studies have found little evidence for this. Firstly, some parliaments have developed mechanisms of political control over the central administrations of parliaments, such as oversight via personal assistants and party staff (Winzen 2014). Secondly, the final decision over what to do still lies with the politicians in all parliaments. And finally, in most parliaments, the extensive delegation to staff is based on a relationship of trust between politicians and staff: MPs delegate tasks to parliamentary administrations, because they trust them to act in a politically neutral and balanced manner. Administrators, in turn, try to anticipate the preferences of MPs in their work, in order to keep their trust (Högenauer and Neuhold 2015). 
The second - positive - scenario is one where politicians delegate tasks to staff, because they are interested in EU politics and wish to increase their parliament's capacity for scrutiny. By asking staff to pre-check incoming EU documents for potentially problematic issues, MPs spread the workload and save their time for deliberation and decision-making on the most important and controversial issues. Indeed, the administrations tend to understand their role as being to create an efficient system of scrutiny that helps politicians prioritize (Högenauer and Neuhold 2015). In this case, one would expect good administrative support systems to have a positive, enabling effect on parliamentary scrutiny. If the aim of delegation is to facilitate scrutiny, then both the size of the administration and the extent of delegation should have a positive effect on the parliament's ability to scrutinize EU policies and thus its level of activity. However, to date, we have little information about the actual impact of administrations. The literature on the level of activism of national parliaments in EU affairs scrutiny has so far still been divided from the literature on administrations and has not yet considered that aspect.

As the evidence so far points in the direction that most national parliaments built their scrutiny systems for EU affairs at least to some extent on the back of the parliamentary administration, the aim of this paper is to study the sources and the effect of the differentiated investments in staff. The question of effect or 'impact' is of course an elusive question, regardless of whether it is studied qualitatively or quantitatively: Most outcomes are the effect of not just one factor, but a complex interplay of mutually reinforcing and/or contradictory factors. Hence, the paper will try to identify the impact of administrations in the context of a range of other factors on the basis of quantitative data from the period 2010-2013.

\section{Studying Delegation and Staff Resources}

The study of parliamentary administrations is important, as past studies suggest that parliamentary administrations matter in policy-making and scrutiny. The idea that parliaments might not just be purely political institutions, but that parliamentary staff might also have some influence, is an old one. In the literature on the staff of the US Congress, the question of staff influence emerged relatively early. In 1952, Meller already argued that staff activity is not just technical and could potentially influence legislative outcomes. Meller even suggests that one could allow legislative and executive staff to pre-discuss 'issues of lesser political magnitude' subject to the subsequent approval of their political masters (Meller 1952). 
Manley does indeed find evidence of substantial influence of staff in the case of the expertise of the staff of the Joint Committee on Internal Review Taxation (Manley 1968). Since the 1970s, the US literature then tried to understand the factors that lead to staff influence, such as trust from politicians, their expertise and their professional status (e.g. Patterson 1970). In addition, DeGregorio argues that delegation depends on the policy issues: Politicians are more likely to delegate in the case of highly technical policies that have low political salience (DeGregorio 1994; DeGregorio and Snider 1995).

Once a European literature on parliamentary administrations really started to emerge in the early 2000s, the question of staff roles and influence also moved quickly to the centre of that literature (e.g. Kungla 2007; Neunreither 2006). Neunreither (2006) argued, for instance, that Members of the European Parliament (MEPs) - and even rapporteurs - are usually not experts on the subject. Firstly, voters rarely vote for an MEP because of specific expertise. Secondly, MEPs may not always be allocated to their preferred committee. And thirdly, the specific legislative proposal that they have to steer through parliament may not fall within their personal expertise. While - in a national context - MPs from a government party can normally look to the government for trusted information, there is no clear link between majority parties and the Commission in the EU. Thus, no party is a 'governing party', and all MEPs have to find alternative sources of information. One of these sources would be the big internal bureaucracy of the EP. Neunreither concludes that the strong trust that MEPs place in that administration is indeed a source of influence for this administration.

This argument is corroborated by Winzen (2011), who argues that committee staff plays the role of 'informant' and thus acts as the institutional memory of the EP and provides background research and advice to MEPs. Their tasks exceed the purely technical and have the potential to shape outcomes. Dobbels and Neuhold (2013) come to a similar conclusion through two case studies on migration policy and fisheries policy. They find that civil servants produce drafts and documents and advise politicians. In addition, in the case of fisheries, staff even performs a 'steering role', in that they 'intervened directly into the policy-making process and tried to steer the process in a direction that went beyond the instructions of MEPs' (p. 24). Dobbels and Neuhold explain this influence through four factors: the legislative entrepreneurship of rapporteurs, the degree of politicized competence of civil servants, the political importance attributed to dossiers and the type of legislative procedure. In the case of national parliaments, Högenauer and Neuhold (2015) study the roles of national parliamentary administrations in EU affairs scrutiny, covering 28 chambers in 21 EU member 
states. They too come to the conclusion that there is substantial delegation to staff. National parliaments have just gained new powers in EU policy-making in the Treaty of Lisbon: They are being sent all EU legislative proposals, which they can review for their compliance with the principle of subsidiarity. In addition, national parliaments receive a wide range of policyrelated documents directly from EU institutions. Both of these changes are expected to improve the ability of parliaments to scrutinize EU legislation, but the processing of this volume of information requires some administrative resources: The EU sends around approximately 25,000 documents per year to each parliament (ibid.).

In this context, Högenauer and Neuhold (2015) find that all parliamentary administrations provide procedural advice to politicians on a routinely basis. Most of them also provide MPs with substantive advice on EU legislative proposals and filter the incoming information on EU legislative proposals, from which they preselect 'relevant' or 'problematic' dossiers. A slightly smaller majority of administrations provide also drafts of final documents, such as reasoned opinions under the EU Early Warning System. As a result, administrators have the opportunity to influence the agenda of their parliament in EU affairs scrutiny through the preselection of dossiers, and to further influence the discussions through their advice. In addition, almost all national parliaments have representatives in Brussels that provide an important coordination function between national parliaments and between a national parliament and the EU institutions (Cooper 2013; Neuhold and Högenauer 2013).

Overall, there is thus a substantial amount of qualitative evidence from different contexts that administrators have an impact on parliamentary output. In the case of the scrutiny of EU policy-making, we would expect administrators to be part of a parliament's capacity for scrutiny, as they generally perform various key functions during the scrutiny process. Yet previous studies have shown that there is a great amount of variation in the number of EU experts that different parliaments employ. Their administrative capacity thus differs widely (Högenauer and Christiansen 2015; Högenauer and Neuhold 2015).

In the first instance, we will try to understand the source of the variation in staff levels. We will investigate three hypotheses:

H1: The number of EU experts is related to the size of the parliament (the number of MPs).

$\mathrm{H} 2$ : The number of EU experts is related to the strength of a parliament.

H3: The number of EU experts is related to the level of public euroscepticism in a country. 
The first of these hypotheses is fairly self-explanatory: European parliaments vary immensely in size - largely due to different sizes of their populations. One can expect larger parliaments to employ more staff, as the staff has to cater to the needs of a greater number of MPs. However, in addition, one can expect the strengths of parliaments in EU affairs scrutiny to play a role. Thus, parliaments that benefit from a greater range of formal powers can perform a wider range of activities and may thus need or want more staff support. In addition, at least some of the stronger parliaments (e.g. Denmark, Sweden, the Netherlands etc.) acquired their powers through inter-institutional battles. One can thus assume that they are motivated to use their powers and willing to invest in their administrative capacity as well. Finally, euroscepticism is often assumed to be a motivating factor for MPs to engage in EU affairs scrutiny (e.g. Raunio 2005). One can thus also expect parliaments in eurosceptic countries to be eager to acquire the necessary resources for EU affairs scrutiny.

Secondly, our aim is to study the impact of administrative capacity. We will focus, in particular, on the effect of administrative capacity on the level of activity of national parliaments in EU affairs scrutiny. We assume that:

H1: Greater numbers of staff dedicated to EU affairs will lead to a more active EU affairs scrutiny on the part of the parliament.

A word of caution is, however, in order. While one might expect administrative resources to have some effect on parliamentary activity, it is unlikely to be the dominant explanatory factor: As the final decisions are still taken by politicians, their motivations are likely to be centre-stage. Thus, the challenge is to try and understand something that would most likely be one explanatory factor among many in a complex context, explaining only a part of the variation in parliamentary activity. Different parliaments may act according to different logics: some may try invest in staff to improve their capacity for scrutiny, while others may delegate EU affairs to staff because the MPs are not interested in that area. In the first instance one would expect parliaments to be particularly active, in the second case one would expect them to be less active.

But what are the competing factors that probably influence parliamentary activity? The answer to this question is not straightforward, as the literature on parliamentary scrutiny was initially focusing on explaining 'level of scrutiny' or 'strength of scrutiny' as the strength of the competences, structures and processes available to a parliament. Thus, in this literature, a 'strong parliament' is a parliament that has a strong potential to hold its government to account, for example. But it tells us little about whether this strong parliament is particularly 
active. Nevertheless, the factors that influence the development of a parliament towards a strong parliament could potentially also lead to a high level of activism.

Raunio (2005) used the fuzzy-set method to explain cross-national variation in the strength of parliamentary scrutiny ability in EU affairs. He looked at five factors: the power of parliament in general (outside EU affairs), public opinion on integration, party positions on integration, political culture and the frequency of minority governments. The only necessary condition was the strength of the parliament in general, whereas a combination of the strength of the parliament and a eurosceptical public opinion emerged as a sufficient condition. This is also in line with Damgaard and Jensen's in-depth study of the Nordic countries, which finds that how a parliament scrutinizes EU affairs is often derived from how it deals with domestic issues more generally (2005). There is thus a pattern of path-dependency in the Europeanization on national parliaments. This further explains why strong parliaments are also strong scrutinizers of EU affairs. Pahre (1997) and Bergmann (2000) also find the euroscepticism plays a role, whereas Karlas (2012) does not find evidence for this.

Post-accession studies to some extent confirm the importance of parliamentary strength (e.g. Karlas 2011; Karlas 2012 for committee strength). In addition, party fragmentation and/or frequent minority governments are conducive to strong systems of EU affairs scrutiny (Karlas 2012). However, they also find that the timing of accession is an important variable (Hamerley 2007; Winzen 2012; Karlas 2012; Tans et al. 2007). Thus, committees that are generally strong in combination with late accession tend to produce strong systems of EU affairs scrutiny (Karlas 2012).

More recently, the literature has started to refocus its attention onto actual parliamentary behavior in recognition of the fact that a parliament with strong powers does not necessarily have to be an active one. That said, Auel et al.'s analysis of 40 chamber in the EU confirms that institutional strength is an important explanatory variable for the level of activity of a parliament (2015a). Interestingly, this association is much stronger for mandates and resolutions than for debates. In addition, there is no statistically significant correlation between the number of mandates/resolutions issued by a parliament and its use of debates. This suggests that different parliaments often specialize on different activities. Finally, institutional strength fails to explain the level of activity of a parliament in the Political Dialogue with the Commission, which indicates that these activities are influenced by a different logic (ibid.). In a separate article, they further find that euroscepticism can be an explanation for the number of resolutions or the time spent in debates (Auel et al. 2015b). 
Whether a parliament is a consensus or majority system and whether it is part of the European Monetary Union can also have an impact on specific elements of parliamentary activity. However, institutional strength emerges again as the main explanatory factor. The study does not take the timing of accession into account, and has thus no specific findings on this.

Overall, what emerges as important competing factors to consider are thus institutional strength and timing of accession and - to a lesser extent - euroscepticism.

$\mathrm{H} 2$ : Parliaments that have strong scrutiny powers in EU affairs are more likely to be active scrutinizers.

H3: Parliaments that joined the EU more recently are more likely to be active scrutinizers.

H4: Parliaments of countries with a higher level of public euroscepticism are more likely to be active scrutinizers.

\section{Data and Methods}

We will use Qualitative Comparative Analysis (QCA) to explore the source of variation in the size of administrative support for EU affairs and in the extent of delegation to EU experts, as well as the effect of that variation on the activity of parliaments in EU affairs. The method used is the fuzzy-set method, which tries to identify the condition variables (i.e. explanatory factors) that explain the outcome variable (similar to a dependent variable). The software is FS/QCA 2.5 (Ragin and Davey 2014). The method concentrates on identifying necessary and sufficient conditions for an outcome. When a condition is necessary, it has to be present for a specific outcome to occur. When a condition is sufficient, the outcome occurs every time the condition is fulfilled, but there may also be other conditions that produce the same outcome (cf. Schneider and Wagemann 2012 for an in-depth discussion of the method). A solution can thus consist of different pathways.

It is also important to note that fuzzy-set QCA is not a probabilistic method that aims to explain the universe of cases on the basis of a sample, but rather a methods that seeks to explain the cases for which you actually have data. It is also a method designed to deal with small- to medium-sized group of cases. This is highly relevant for the analysis of national parliaments in the EU, where there are only 28 parliaments comprising 41 chambers (i.e. upper and lower houses). In this paper the analysis will cover 40 chambers (excluding 
Croatia, which joined relatively recently). QCA is thus on firmer ground than probabilistic methods, and is becoming increasingly popular as a means to analyze national parliaments in the EU (cf. Raunio 2005; Karlas 2012).

An overview over the explanatory and outcome variables is presented in Table 1. In order to measure the outcome variable 'level of activity', we rely on Auel et al.'s activity score (2015a). It takes into account the number of resolutions and mandates issue by parliaments, the time they spent in meetings of European Affairs committees (EACs), the time spent debating EU issues in the plenary and the opinions adopted by the parliament under the political dialogue with the European Commission. It covers the years 2010-2012. In order to take a closer look at the role of administrators in the political dialogue and the EWS, we have also collected data on the number of opinions (political dialogue) and reasoned opinions (EWS) issued between 2010 and 2013 from the Commission's annual reports on the political dialogue.

For the independent variables, we use Auel et al.'s indicator in order to measure the institutional strength of a parliament in EU affairs scrutiny (2015a). It is one of the few indicators that includes upper houses as distinct chambers. While upper houses tend to be the weaker chamber, they have the same rights as lower houses under the EWS and the political dialogue and should therefore be seen as independent actors. Overall, institutional strength is measured on three dimensions: access to information, scrutiny infrastructure and oversight.

The date of accession was coded on a scale from 0 to 6 , with zero being the founding members and 6 Bulgaria and Romania. Croatia is not yet included into the data set, as they were not an active member during the period of investigation. The scores for public euroscepticism are taken from Karlas 2012, and are an aggregate if the Eurobarometer surveys of 2001-2008.

The number of EU staff and the total number of staff employed by a chamber are based on Högenauer and Christiansen (2015) and COSAC reports. The number of MPs per chamber is based on the figures for 2014/2015.

Table 1: Overview over the conditions

\begin{tabular}{|l|l|l|l|l|l|l|}
\hline & $\begin{array}{l}\text { Euroscepticism in } \\
\text { the population }\end{array}$ & $\begin{array}{l}\text { Accession } \\
\text { wave }\end{array}$ & $\begin{array}{l}\text { Level of } \\
\text { activity }\end{array}$ & $\begin{array}{l}\text { No. of } \\
\text { EU } \\
\text { staff }\end{array}$ & $\begin{array}{l}\text { Institutional } \\
\text { strength }\end{array}$ & $\begin{array}{l}\text { No. of } \\
\text { MPs }\end{array}$ \\
\hline
\end{tabular}




\begin{tabular}{|c|c|c|c|c|c|c|}
\hline $\begin{array}{l}\text { Austria } \\
\text { Bundesrat }\end{array}$ & 64 & 4 & .10 & 7.5 & .45 & 61 \\
\hline $\begin{array}{l}\text { Austria } \\
\text { Nationalrat }\end{array}$ & 64 & 4 & .22 & 7.5 & .51 & 183 \\
\hline $\begin{array}{l}\text { Belgium } \\
\text { Chamber }\end{array}$ & 33 & 0 & .18 & 6.0 & .24 & 150 \\
\hline Belgium Senate & 33 & 0 & .16 & 4.0 & .16 & 71 \\
\hline Bulgaria & 46 & 6 & .10 & 10.0 & .41 & 240 \\
\hline Cyprus & 55 & 5 & .10 & 7.0 & .27 & 80 \\
\hline Czech Chamber & 53 & 5 & .33 & 5.0 & .58 & 200 \\
\hline Czech Senate & 53 & 5 & .33 & 7.0 & .59 & 81 \\
\hline Denmark & 38 & 1 & .39 & 6.0 & .69 & 179 \\
\hline Estonia & 47 & 5 & .30 & 6.0 & .67 & 101 \\
\hline Finland & 57 & 4 & .60 & 7.0 & .84 & 200 \\
\hline France AN & 50 & 0 & .21 & 28.0 & .55 & 577 \\
\hline France Senate & 50 & 0 & .16 & 15.0 & .56 & 348 \\
\hline $\begin{array}{l}\text { Germany } \\
\text { Bundesrat }\end{array}$ & 41 & 0 & .24 & 6.0 & .62 & 69 \\
\hline $\begin{array}{l}\text { Germany } \\
\text { Bundestag }\end{array}$ & 41 & 0 & .34 & 44.5 & .78 & 631 \\
\hline Greece & 44 & 2 & .08 & 10.0 & .26 & 200 \\
\hline Hungary & 60 & 5 & .10 & 7.0 & .48 & 386 \\
\hline Ireland Dail & 26 & 1 & .19 & 5.5 & .46 & 166 \\
\hline Ireland Senate & 26 & 1 & .15 & 5.5 & .47 & 60 \\
\hline Italy Camera & 49 & 0 & .29 & 18.0 & .46 & 630 \\
\hline Italy Senate & 49 & 0 & .25 & 16.0 & .54 & 315 \\
\hline Latvia & 64 & 5 & .15 & 6.0 & .53 & 100 \\
\hline Lithuania & 40 & 5 & .26 & 23.0 & .73 & 141 \\
\hline Luxemburg & 23 & 0 & .16 & 6.0 & .40 & 60 \\
\hline Malta & 52 & 5 & .07 & 4.0 & .46 & 69 \\
\hline NL EersteKamer & 26 & 0 & .06 & 2.0 & .54 & 75 \\
\hline $\begin{array}{l}\text { NL } \\
\text { TweedeKamer }\end{array}$ & 26 & 0 & .30 & 11.0 & .66 & 150 \\
\hline Poland Sejm & 41 & 5 & .14 & 11.0 & .44 & 460 \\
\hline Poland Senate & 41 & 5 & .13 & 10.0 & .45 & 100 \\
\hline Portugal & 46 & 3 & .34 & 5.0 & .43 & 230 \\
\hline $\begin{array}{l}\text { Romania } \\
\text { Chamber }\end{array}$ & 34 & 6 & .16 & 10.0 & .35 & 405 \\
\hline
\end{tabular}




\begin{tabular}{|l|l|l|l|l|l|l|}
\hline Romania Senate & 34 & 6 & .13 & 28.0 & .34 & 137 \\
\hline Slovakia & 44 & 5 & .21 & 9.0 & .49 & 150 \\
\hline $\begin{array}{l}\text { Slovenia } \\
\text { Chamber }\end{array}$ & 48 & 5 & .19 & 6.0 & .60 & 90 \\
\hline Slovenia Senate & 48 & 5 & .03 & 1.0 & .21 & 40 \\
\hline Spain Congreso & 33 & 3 & .23 & 3.0 & .40 & 350 \\
\hline Spain Senate & 33 & 3 & .22 & 3.0 & .39 & 266 \\
\hline Sweden & 52 & 4 & .56 & 7.0 & .72 & 349 \\
\hline $\begin{array}{l}\text { UK House of } \\
\text { Commons }\end{array}$ & 65 & 1 & .14 & 15.0 & .52 & 650 \\
\hline $\begin{array}{l}\text { UK House of } \\
\text { Lords }\end{array}$ & 65 & 1 & .28 & 24.0 & .47 & 760 \\
\hline $\begin{array}{l}\text { Austria } \\
\text { Bundesrat }\end{array}$ & 64 & 4 & .10 & 7.5 & .45 & 61 \\
\hline
\end{tabular}

Wave of accession : $0=$ original member states, $6=$ most recent accession.

'level of activity' and 'institutional strength' based on Auel et al.'s activity score (2015a)

‘Public euroscepticism’ based on Karlas 2012.

The number of EU staff and the total number of staff employed by a chamber are based on Högenauer and Christiansen (2015) and COSAC reports. The number of MPs per chamber is based on the figures for 2014/2015.

In order to use the data for a fuzzy-set analysis, it had to be transformed to fit a scale from 0 to 1 (cf. Table 2). If a case gets a 1 for a certain condition, it means that it fully fulfils that condition (e.g. the parliament has a large support staff). A 0 means that the case does not fulfil the condition (e.g. it does not have a large support staff). In addition, one needs to define the cross-over point (the new 0.5 point). This point is important, as the fuzzy-set method is a settheoretic method and the 0.5 point defines whether a case belongs into the set of cases that fulfil a condition or not. For example, cases that have a value of $>0.5$ on Euroscepticism are deemed to be (more or less) Eurosceptic, whereas cases that have a $<0.5$ are (more or less) not Eurosceptic.

The case of Euroscepticism is easy, for example: we chose 50 as the cross-over point, as a country where $50 \%$ of the population is Eurosceptic is logically neither Eurosceptic nor not Eurosceptic. The same applies to 'strength', where the original 0.5 point could be used to distinguish between chambers that are fairly strong and those that are not. By contrast, the condition 'activity' is tricky: the original indicators were already on a scale from 0 to 1 , and could thus have been used directly in the fuzzy-set analysis. However, there are almost no 
cases above 0.5 . This is a problem, as an analysis where (almost) all cases are 'not active' does not work. We have thus transformed those indicators by defining the 0.5 point as being close to the median case (here: 0.20 or the original indicator). That way, the conditions measure which cases are 'comparatively active' and which cases are not 'comparatively active'.

We have also chosen the median as a cross-over point for No. of EU staff (8) and No. of MPs (175), as there are not obvious gaps between cases that would justify the choice of a different point.

The indicators for most variables were then transformed into a 6-point scale by recoding the new variables in the following way: $0-0.9=0 ; 0.1-0.29=0.2 ; 0.3-0.49=0.4 ; 0.51-0.69=0.6 ; 0.7-$ $0.89=0.8 ; 0.9-1=1$.For the purpose of this analysis, we have transformed most variables to fit a six-point scale $(0,0.2,0.4,0.6,0.8,1)$. The exception is the wave of accession. As we are particularly interested in the effect of recent accession, we have defined the 2007 accession as 1 , the 2004 accession as 0.75 , so that these two waves are in the set of 'recent accessions'. The accessions of 1995, 1986, 1981, 1973 and original member states were coded as 0.4, 0.3, $0.2,0.1$ and 0 respectively, so that they are part of the set of 'not recent accessions'.

Table 2: Fuzzy-set score for the different indicators

\begin{tabular}{|l|l|l|l|l|l|l|}
\hline & sizeadmin & eurosceptic & strength & NoMPs & active & recentaccession \\
\hline Austria Bundesrat & 0.4 & 1 & 0.4 & 0 & 0.2 & 0.4 \\
\hline Austria Nationalrat & 0.4 & 1 & 0.6 & 0.6 & 0.6 & 0.4 \\
\hline Belgium Chamber & 0.4 & 0.2 & 0 & 0.4 & 0.4 & 0 \\
\hline Belgium Senate & 0.2 & 0.2 & 0 & 0 & 0.4 & 0 \\
\hline Bulgaria & 0.6 & 0.4 & 0.4 & 0.6 & 0.2 & 1 \\
\hline Cyprus & 0.4 & 0.8 & 0.2 & 0.2 & 0.2 & 0.75 \\
\hline Czech Chamber & 0.2 & 0.6 & 0.6 & 0.6 & 0.8 & 0.75 \\
\hline Czech Senate & 0.4 & 0.6 & 0.6 & 0.2 & 0.8 & 0.75 \\
\hline Denmark & 0.4 & 0.2 & 0.8 & 0.6 & 0.8 & 0.1 \\
\hline Estonia & 0.4 & 0.4 & 0.8 & 0.2 & 0.6 & 0.75 \\
\hline Finland & 0.4 & 0.8 & 1 & 0.6 & 1 & 0.4 \\
\hline France AN & 0.8 & 0.6 & 0.6 & 0.8 & 0.6 & 0 \\
\hline France Senate & 0.6 & 0.6 & 0.6 & 0.8 & 0.4 & 0 \\
\hline Germany Bundesrat & 0.4 & 0.2 & 0.8 & 0 & 0.6 & 0 \\
\hline
\end{tabular}




\begin{tabular}{|l|l|l|l|l|l|l|}
\hline Germany Bundestag & 1 & 0.2 & 1 & 1 & 0.8 & 0 \\
\hline Greece & 0.6 & 0.4 & 0.2 & 0.6 & 0.2 & 0.2 \\
\hline Hungary & 0.4 & 0.8 & 0.4 & 0.8 & 0.2 & 0.75 \\
\hline Ireland Dail & 0.2 & 0 & 0.4 & 0.4 & 0.4 & 0.1 \\
\hline Ireland Senate & 0.2 & 0 & 0.4 & 0 & 0.2 & 0.1 \\
\hline Italy Camera & 0.6 & 0.4 & 0.4 & 1 & 0.6 & 0 \\
\hline Italy Senate & 0.6 & 0.4 & 0.6 & 0.6 & 0.6 & 0 \\
\hline Latvia & 0.4 & 1 & 0.6 & 0.2 & 0.2 & 0.75 \\
\hline Lithuania & 0.8 & 0.2 & 0.8 & 0.4 & 0.6 & 0.75 \\
\hline Luxemburg & 0.4 & 0 & 0.2 & 0 & 0.4 & 0 \\
\hline Malta & 0.2 & 0.6 & 0.4 & 0 & 0 & 0.75 \\
\hline NL EersteKamer & 0 & 0 & 0.6 & 0.2 & 0 & 0 \\
\hline NL TweedeKamer & 0.6 & 0 & 0.8 & 0.4 & 0.6 & 0 \\
\hline Poland Sejm & 0.6 & 0.2 & 0.4 & 0.8 & 0.2 & 0.75 \\
\hline Poland Senate & 0.6 & 0.2 & 0.4 & 0.2 & 0.2 & 0.75 \\
\hline Portugal & 0.2 & 0.4 & 0.4 & 0.6 & 0.8 & 0.3 \\
\hline Romania Chamber & 0.6 & 0.2 & 0.2 & 0.8 & 0.4 & 1 \\
\hline Romania Senate & 0.8 & 0.2 & 0.2 & 0.4 & 0.2 & 1 \\
\hline Slovakia & 0.6 & 0.4 & 0.4 & 0.4 & 0.6 & 0.75 \\
\hline Slovenia Chamber & 0.4 & 0.4 & 0.8 & 0.2 & 0.4 & 0.75 \\
\hline Slovenia Senate & 0 & 0.4 & 0 & 0 & 0 & 0.75 \\
\hline Spain Congreso & 0.2 & 0.2 & 0.2 & 0.8 & 0.6 & 0.3 \\
\hline Spain Senate & 0.2 & 0.2 & 0.2 & 0.6 & 0.6 & 0.3 \\
\hline Sweden & 0.4 & 0.6 & 0.8 & 0.8 & 1 & 0.4 \\
\hline UK House & 0.6 & 1 & 0.6 & 1 & 0.2 & 0.1 \\
\hline Commons & & & 0.4 & 1 & 0.6 & 0.1 \\
\hline UK House of Lords & 0.8 & 1 & 0.4 & & & 0.6 \\
\hline
\end{tabular}

\section{The EU Staff of National Parliaments: the Source of Diversity}

There has been no convergence in the level of staffing of different parliaments in recent years. This is in part due to the fact that parliaments have been exposed to two opposing trends. On the one hand, the received new powers under the Treaty of Lisbon that require them to process a large number of documents in relatively little time and to respond in legalistic terms. This could be expected to lead to an investment into additional staff, especially on the 
part of smaller parliaments or very active parliaments. However, on the other hand, Europe has been exposed to a public debt crisis, which could lead to hiring stops or cut-backs. While it is difficult to obtain data on the staffing levels of the mid-2000s, we were able to retrospectively collect data for 15 cases. Overall, the total number of EU experts in those fifteen cases rose from 144 to 165.5 between 2006 and 2011. However, a closer look shows that five cases, Bulgaria, Sweden, Estonia, the Czech Chamber of Deputies and Portugal, experienced no change during that period. Only six cases employed more EU experts in 20112013 than in 2006. The biggest changes took place in the Austrian parliament (an increase from 10 to 15 staff) and the German Bundestag (from 29.5 to 44.5 staff). The German Bundesrat, the Belgian Senate, the Luxemburgish parliament and the Belgian Chamber of Deputies increased their EU staff by one to three staff members. However, there are also four cases where the number of EU experts diminished over time. The UK House of Commons and the Cypriot parliament reduce their EU staff by one, whereas the French Senate and the Finish parliament reduced their staff by two. In general, the reason cited was the crisis. There is thus no uniform trend, and the German Bundestag has become even more of an outlier with extremely high staffing levels.

Another trend towards divergence lies in the organization of EU staff. While some parliaments rely exclusively on their EACs for to scrutinize EU affairs, while others have mainstreamed this activity and rely primarily on their sectoral committees (see Gattermann et al. 2015). Yet others use a mixed system where the EAC and the relevant sectoral committee both influence the final decisions of parliament. Similarly, some chambers concentrate their staff in the EAC secretariat, some give their sectoral committees independent resources and yet others have a central unit, research unit or legal unit responsible for all committees.

The one (rare) source of converge is that all but two parliaments (Slovakia and Bulgaria) currently have a representative in Brussels who maintains inter-parliamentary relations on a day-to-day basis, alerts the national parliament to new EU initiatives and facilitates contacts with the EU institutions (cf. Neuhold and Högenauer 2013).

Thus, despite the fact that most national parliaments delegate an extensive (and similar) set of tasks to the EU experts among their staff (cf. Högenauer and Neuhold 2015), the number of EU experts available to them is a source of great variation. The various chambers are employing between one and 44.5 EU experts (cf. Table 1).

In trying to understand why some chambers employ comparatively large numbers of EU experts, we have first tested the data for 'necessary conditions', i.e. for conditions that have to 
be present for the chamber to employ large numbers of staff. Neither of the individual conditions - a eurosceptic population, a strong chamber, a large chamber - are a necessary condition for a large number of EU experts (cf. Table 3). However, the combination of a large chamber or a strong chamber is an (almost) necessary condition. What this means is that almost all chambers with large staff support are also either big chambers or strong chambers.

Table 3: Necessary concitions for a large EU staff

\begin{tabular}{|l|l|l|}
\hline & Consistency & Coverage \\
\hline No. of MPs & 0.76 & 0.73 \\
\hline Strength & 0.78 & 0.73 \\
\hline Euroscepticism & 0.64 & 0.68 \\
\hline No of MPs + Strength & 0.92 & 0.66 \\
\hline
\end{tabular}

The next step is to test for sufficient conditions, or sufficient combinations of conditions. As we have three potential condition variables (Euroscepticism in the population, the strength of the chamber and the size of the chamber), eight different combinations of variables are possible. These variations, their empirical occurrence and their consistency values are displayed in Table 4. All theoretically possible combinations do indeed contain empirical cases. As a result, there are no logical remainders where we have no empirical data on the result of a certain combination of variables. 
Table 4: Truth table

\begin{tabular}{|l|l|l|l|l|l|}
\hline eurosceptic & strength & nomps & cases sizeadmin & $\begin{array}{l}\text { raw } \\
\text { consist. }\end{array}$ \\
\hline 1 & 0 & 1 & UK House of Lords, Hungary, & 1 & $\mathbf{0 . 9 3}$ \\
\hline 0 & 1 & 1 & $\begin{array}{l}\text { German Bundestag, Italian Senate, } \\
\text { Denmark }\end{array}$ & $\mathbf{0 . 8 9}$ \\
\hline 1 & 1 & 0 & Czech Senate, Latvia & 1 & $\mathbf{0 . 8 8}$ \\
\hline 1 & 1 & 1 & $\begin{array}{l}\text { French Assemblée Nationale, French } \\
\text { Senate, UK House of Commons, Austria } \\
\text { Nationalrat, Finland, Sweden, Czech } \\
\text { Chamber }\end{array}$ & $\mathbf{0 . 8 8}$ \\
\hline 1 & 0 & 0 & $\begin{array}{l}\text { Austrian Bundesrat, Cyprus, Malta } \\
\text { Greece, Bulgaria, Romanian Chamber of } \\
\text { Deputies, Polish Sjem, Italian Camera, } \\
\text { Portuga, Spanish Senate, Spanish } \\
\text { Congreso }\end{array}$ & 0 & 0.79 \\
\hline 0 & 0 & 1 & $\begin{array}{l}\text { Lithuania, Dutch Tweede Kamer, German } \\
\text { Bundesrat, Estonia, Dutch Eerste Kamer }\end{array}$ & 0 & 0.77 \\
\hline 0 & 1 & 0 & 0 & $\begin{array}{l}\text { Romanian Senate, Polish Senate, } \\
\text { Slovakia, Luxembourg, Slovenian } \\
\text { Chamber of Deputies, Belgian Chamber of } \\
\text { Deputies, Irish Senate, Belgian Senate, } \\
\text { Irish Dail, Slovenian Senate }\end{array}$ & 0.69 \\
\hline
\end{tabular}

Strong consistency in bold

Cases with large staff in bold (0.8 or 1), and with somewhat large staff in italics (0.6).

As we can see, four combinations have a high consistency (above 0.85 threshold). Through a process of logical minimization, these four combinations can in fact be expressed through three solution terms for the intermediate solution:

Eurosceptic*strength $(0.85 ; 0.61)$

Eurosceptic*nomps $(0.81 ; 0.53)$

Strength*nomps $(0.84 ; 0.58)$

The numbers in brackets express the consistency and coverage of each term. The solution as a whole has a consistency of 0.78 and a coverage of 7.4. The coverage and consistency are acceptable, although a higher consistency would be desirable. What the solution means is that there are three different pathways to a large number of EU experts: Parliaments have a large 
EU staff if they are strong and the population in their country is Eurosceptic, or if the population is Eurosceptic and there are big, or if they are strong and big. In general, it can be said that all three conditions - Euroscepticism, the size of the chamber and the strength of the chamber - do indeed influence the number of EU experts employed by a chamber.

Nevertheless, the overall picture is one of diversity among parliaments. A look at the truth table shows that, regrettably, some cases with relatively large numbers of EU staff are not well explained by the solution. Thus, Lithuania and Romania, in particular, fail to be explained by the solution. In the case of Romania, this may have something to do with a culture of clientelism. The Romanian Senate, in particular, is the second best-staffed chamber behind the German Bundestag. In light of the fact that the Romanian Senate is fairly inactive in EU affairs its eagerness to invest in EU experts is hard to explain through rational arguments.

\section{The effect of different levels of staff support}

As discussed previously, the impact of the number of EU experts on the level of activity of parliaments is explored in the context of other explanatory conditions, such as the date of accession, the strength of the parliament and the level of Euroscepticism in the parliament.

We first explored the data for necessary conditions for a high level of activity (Table 5).

Table 5: Test for necessary conditions for an active parliament

\begin{tabular}{|l|l|l|}
\hline & Consistency & Coverage \\
\hline sizeadmin & 0.73 & 0.73 \\
\hline eurosceptic & 0.60 & 0.65 \\
\hline strength & 0.80 & 0.76 \\
\hline recentaccession & 0.47 & 0.53 \\
\hline
\end{tabular}

The test shows that there is indeed a relatively strong overlap between strong parliaments and active parliaments. With a consistency of .8 and a coverage of .76 'strength' comes close to being a necessary condition for high activity. This is unsurprising, given that the existing literature on national parliaments already suggests that 'strength' is an important factor. 
Among the other conditions, a large EU staff ('sizeadmin') also achieves relatively strong values for consistency and coverage, albeit not enough to consider it a necessary condition.

In the test of sufficient conditions, sixteen different combinations of outcome variables are theoretically possible. Fourteen of these combinations are actually represented in the empirical data. The fact that almost all combinations are covered makes for a relatively robust analysis, as it reduces the need to rely on theoretical assumptions to fill the remaining gaps. With a consistency threshold of 0.85 , we obtain three solution terms for the intermediate solution:

$\sim$ recentaccession*strength (consistency of 0.82 ; coverage of 0.64 )

$\sim$ recentaccession*sizeadmin $(0.83 ; 0.62)$

strength* eurosceptic*sizeadmin $(0.91 ; 0.54)$

Overall, the solution covers a large proportion of cases (0.79) and has a consistency of 0.77 , which is acceptable. However, what is disappointing is that three of the strong cases of 'activity' ( 0.8 or above) are again not covered by the solution: the Czech Chamber and Senate and Portugal. The problem with Portugal is not entirely surprising, as the high score for activity is somewhat artificial. Portugal adopts far more opinions than any other parliament, which raises the activity score, but many of these opinions do not contain much substance. It is thus a case of quantity without quality. However, the fact that other strong cases fall out of the solution is again a reflection on the level of diversity among parliaments.

Overall, what the solution means is that parliaments of old member states that have much EU staff or strong scrutiny powers tend to be active. In addition, parliaments that have strong scrutiny powers, much EU staff and where the population is not Eurosceptic tend to be active. Thus, while Kalas (2012) found that the parliaments of member states that joined recently are more likely to have strong scrutiny powers in EU affairs, our findings suggest that this strength does not translate into actual activity.

The fact that certain conditions only work of parliaments from old member states suggests that there may be different dynamics at work in different member states. We have thus tested the conditions 'euroscepticism', 'size of the administration' and 'strength' again, but this time separately on old and on new member states.

In the case of the EU-15, the fuzzy-set analysis with a cut-off point of 0.85 results in two solution terms for the intermediate solution: strong parliaments are active (0.82); and 
parliaments with a large EU staff are active (0.83). The solution as a whole has a good consistency which is similar to that for the EU-27 (0.79), but it also has an excellent coverage (0.87). All key examples of active parliaments are covered (Finland, Sweden, Denmark, the German and Italian chambers, the House of Lords). There are only three cases that are in the 'much EU staff' group that are not covered by the solution: Portugal, which is an exceptional case (see above), and the two Spanish chambers, which are among the least active chambers in the 'active' group. Overall, the solution thus provides a good explanation for activity. What is worth noting is that it contains the main ingredients of the solution for the EU-27: strength and a certain number of EU staff. What is different is that the absence of Euroscepticism no longer has a positive influence.

However, when we look at the EU-12 that joined in 2005 and 2007, the picture is quite different. Firstly, none of the individual truth table rows had a consistency above the 0.8 threshold, which meant that the bar for consistency had to be lowered to 0.75 to generate a solution. The intermediate solution contains two terms:

Strength* ${ }^{*} \operatorname{sizeadmin}(0.71 ; 0.79)$

Strength* euroscepticism $(0.75 ; 0.75)$

The overall consistency of the solution is 0.71 and the coverage 0.86 . The coverage is thus good, but the consistency somewhat weak and fails to cover one of the five cases of active parliaments (Slovakia). More importantly, while 'strength' is still a condition for an active parliament, the absence of Euroscepticism plays a role, unlike in the EU-15. In addition, the absence of a large body of EU staff is part of the explanation of activity, whereas its presence was part of the explanation in the case of the EU-15.

\section{Conclusion}

The investments of national parliaments in EU affairs staff differ widely. There has been no sign of convergence in recent years, as the new opportunities for EU affairs scrutiny in the Treaty of Lisbon have created incentives for greater investments, while the sovereign debt crisis in the Eurozone has created pressures to reduce public expenditures. The only element of convergence is that almost all parliaments have at least one administrator in Brussels who assists them in the gathering of information and in the coordination with other national parliaments. 
The source of the divergence in investments in staff lies in a variety of factors. Public Euroscepticism, a greater strength of the scrutiny powers of parliaments and a greater size in terms of MPs all seem to be linked to greater investments in staff.

But what is the effect of parliaments having different administrative resources? Is there a visible effect on how actively parliaments engage in EU affairs scrutiny? Despite the fact that administrative support is one factor among many, and that the motivations of politicians undoubtedly play a decisive role, our findings suggest that administrative capacity makes a difference. Across the EU-27, strength and/or a large number of EU experts are key explanatory conditions in combination with long membership in the EU or with the absence of Euroscepticism. Among the EU-15, the states that joined the EU before 2004, the impact of administrative resources is even stronger, as strong scrutiny powers or a larger number of EU staff are the key explanatory conditions for active parliaments. However, if we only look at the twelve states that joined in 2004 and 2007, there seems to be great diversity across the active states, which makes it difficult to find a strong explanation. In general, strength seems to be a key factor, in combination with small staff resources or a pro-European population. In fact, five out of seven chambers with larger staff resources show a low level of activity - and often a very low level of activity in comparison with other chambers. In some cases - such as the very inactive Romanian Senate - the fairly high staffing levels are clearly not an expression of ambition.

To conclude, staff resources generally appear to facilitate active scrutiny of EU affairs. However, it is also clear that not every parliament or chamber of a parliament has made active scrutiny of EU affairs its priority. As a result, the expectations that are placed on staff are not always the same and we cannot automatically assume that more staff leads to more or better scrutiny. To complicate matters further, even active chambers can have different priorities. For instance, some chambers see themselves as debating chambers, whereas others prioritize mandating, whereas a third group prioritizes the political dialogue (cf. Rozenberg and Hefftler 2015). Those priorities will also influence to what extent and in what ways administrative staff can support their chamber. 


\section{Bibliography}

Auel K., O. Rozenberg, A. Tacea 2015b. 'To Scrutinize or Not to Scrutinize? Explaning Variation in EU-Related Activities in National Parliaments', West European Politics 38, 2, 282-304.

Auel K., O. Rozenberg, A. Tacea. 2015a. ,Fighting Back? And, If so, How? Measuring Parliamentary Strength and Activity in EU Affairs', in C. Hefftler, C. Neuhold, O. Rozenberg and J. Smith (eds), The Palgrave Handbook of National Parliaments and the European Union. Basingstoke: Palgrave MacMillan.

Bergman T. 2000. 'The European Union as the Next Step of Delegation and Accountability', European Journal of Political Research, 37, 415-29.

Carter C. 2008. 'Identifying Causality in Public Institutional Change: The Adaptation of the National Assembly for Wales to the European Union', Public Administration, 86, 2, 345-61. Cooper I. 2013. 'A Yellow Card for the Striker: How National Parliaments Defeated EU Strikes Regulation', Paper presented at the EUSA Biennial Conference in Baltimore, 9-11 May 2013.

COSAC 2008. '9th Bi-Annual Report: Developments in the European Union Procedures and Practices Relevant to Parliamentary Scrutiny', May 2008, retrieved from: www.cosac.eu/documents/bi-annual-reports-of-cosac/ (accessed 15/08/2013).

Damgaard E. and H. Jensen. 2005. 'Europeanisation of executive-legislative relations: Nordic perspectives', The Journal of Legislative Studies, 11, 3-4, 394-411.

DeGregorio C. 1994. 'Congressional Committee Staff as Policy Making Partners in the U.S. Congress'. Congress and the Presidency, 21, 49-66.

DeGregorio C. and K. Snider. 1995. 'Leadership Appeal in the U.S. House of Representatives: Comparing Officeholders and Aides'. Legislative Studies Quarterly, 20, 491511.

Dobbels M. and C. Neuhold. 2013. "'The Roles Bureaucrats Play"': The Input of European Parliament (EP) Administrators into the Ordinary Legislative Procedure: A Case Study Approach'. Journal of European Integration, 35, 4, 375-90.

Egeberg M., A. Gornitzka, J. Trondal and M. Johannessen. 2013. 'Parliament Staff: Unpacking the Behaviour of Officials in the European Parliament', Journal of European Public Policy 20, 4, 495-514. 
Gattermann K., A.L. Högenauer, Huff. 2015. 'research note: studying a new phase of europeanisation of national parliaments', European Political Science, doi:

10.1057/eps.2015.56, 16. October 2015.

Hamerly I. 2007. 'The Timing of EU Membership and its Effects on National Legislative Oversight over EU Affairs'. Presented at the American Political Science Association Conference, Chicago, IL, USA, August 2007.

Högenauer A.L. and C. Neuhold. 2015. 'National Parliaments after Lisbon: Administrations on the Rise?' West European Politics, 38, 2, 335-54.

Högenauer A.L. and T. Christiansen. 2015, 'The Role of Parliamentary Administrations in the EU', in C. Heffler, C. Neuhold, O. Rozenberg, J. Smith, The Palgrave Handbook on National Parliaments and the European Union, Basignstoke: Palgrave.

Högenauer A.L., C. Neuhold C. and T. Christiansen. 2016, Parliamentary Administrations in the European Union, London: Palgrave.

Karlas J. 2011. 'Parliamentary Control of EU Affairs in Central and Eastern Europe:

Explaining the Variation'. Journal of European Public Policy, 18, 2, 258-73.

Karlas J. 2012. 'National Parliamentary Control of EU Affairs: Institutional Design after Enlargement', West European Politics, 35, 5, 1095-113.

Kungla T. 2007. "'Raising the Game": Administrative Reform of the European Parliament General Secretariat', in M. Bauer and C. Knill (eds), Management Reforms in International Organizations. Baden-Baden: Nomos Verlagsgesellschaft, 71-83.

Manley J.F. 1968. 'Congressional Staff and Public Policy-Making: The Joint Committee on Internal Revenue Taxation', The Journal of Politics, 30, 4, 1046-67.

Meller N. 1952. 'The Policy Position of Legislative Service Agencies', The Western Political Quarterly, 5, 109-23.

Neuhold C. and A.L. Högenauer. 2013. 'Administrators Networking EU Affairs? The Role of Parliamentary Officials in Inter-Parliamentary Coordination and Control.' Paper presented at the EUSA Biennial Conference in Baltimore, 9-11 May 2013.

Neunreither K. 2006. 'Elected legislators and their unelected assistants in the European Parliament.' The Journal of Legislative Studies, 8, 4, 40-60. 
Page E. and B. Jenkins. 2005. Policy Bureaucracy: Government with a Cast of Thousands. Oxford: Oxford University Press.

Patterson S. 1970. 'The Professional Staffs of Congressional Committees'. Administrative Science Quarterly, 15, 22-37.

Phare R. 1997. 'Endogenous Domestic Institutions in Two-level Gavmes and Parliamentary Oversight of the European Union', Journal of Conflict Resolution, 41, 1, 147-74.

Ragin C. and S. Davey. 2014. Fuzzy-Set/Qualitative Comparative Analysis 2.5. Irvine, California: Department of Sociology, University of California.

Raunio T. 2005. 'Holding governments accountable in European affairs: Explaining crossnational variation', The Journal of Legislative Studies, 11, 3-4, 319-42.

Rozenberg O. and A. Tacea. 2015, 'Introduction', in C. Hefftler, C. Neuhold, O. Rozenberg and J. Smith (eds), The Palgrave Handbook of National Parliaments and the European Union. Basingstoke: Palgrave MacMillan.

Schneider C. and C. Wagemann. 2012. Set-Theoretic methods for the Social Sciences: A Guide to Qualitative Comparative Analysis, Cambridge: Cambridge University Press. Tans O., C. Zoethout, J. Peters (eds). 2007. National Parliaments and European Democracy: A Bottom-up Approach to European Constitutionalism. Groningen: Europa Law Publishing. Winzen T. 2011. 'Technical or Political? An Exploration of the Work of Officials in the Committees of the European Parliament', The Journal of Legislative Studies, 17, 1, 27-44.

Winzen T. 2012. 'National Parliamentary Control of European Union Affairs: A CrossNational and Longitudinal Comparison', West European Politics, 35, 3, 657-72.

Winzen, T. 2014. 'Bureaucracy and Democracy: Intra-Parliamentary Delegation in European Union Affairs.' Journal of European Integration 36, 7, 677-95. 